\section{Awangarda i tekst dromoskopowy}

Michalina Kmiecik

TEKSTY DRUGIE 2018, NR 1, S. 272-296
Tekst powstał w ramach projektu Style zachowań awangardowych (program Sonata $10, \mathrm{nr}$ rej. 2015/19/D/ $\mathrm{HS} 2 / 01003$ ) finansowanego przez Narodowe Centrum Nauki.

DOI: 10.18318/td.2018.1.16

\section{Dromomania}

Jednym z kluczowych dla zrozumienia i przyswojenia awangardowego imaginarium pojęć jest $\mathrm{z}$ całą pewnością d ro m o m a n i a. Słowo to, choć częściej spotykane i używane w podręcznikach psychologii czy psychiatrii, wydaje się świetnie opisywać wielokrotnie już poddawany analizie progresywizm nowej sztuki, jej zamiłowanie do szybkości i rozwoju, nieprzerwaną presję innowacyjności. Oznacza ono bowiem nie tylko potrzebę nieustannego przemieszczania się, ale także porzucania własnej tożsamości i osobowości. Ian Hacking w książce Mad Travelers w ten sposób opisuje pierwszy odnotowany przypadek dromomanii:

The young man's name was Albert; he was an occasional employee of the local gas company, and the first fugueur. He became notorious for his extraordinary expeditions to Algeria, Moscow, Constantinople. He travelled obsessively, bewitched, often without identity papers and sometimes without

\section{Michalina Kmiecik}

- literaturoznaw-

czyni, pracuje na

Wydziale Polonistyki

U). Autorka książek:

Oblicza miejsca.

Topiczne iatopiczne

wyobrażenia prze-

strzeni w poezji Juliana

Przybosia (2013), Drogi

negatywności. Nurt

estetyczno-religijny

w poezji i muzyce

awangardowej $w X X$

wieku (2016) oraz

artykułów z zakresu

historii literatury XX-

-wiecznej. Redaktorka serii awangarda/rewi-

zje w Wydawnictwie

UJ. Zajmuje się teorią i praktyką awangardy oraz intermediami.

Kontakt: michalina.

kmiecik@gmail.com 
identity, not knowing who he was or why he travelled, and knowing only where he was going next. When he "came to" he had little recollection of where he had been, but under hypnosis he would recall lost weekends or lost years. [...]

Fugue became a medical disorder in its own right, with earthly labels like Wandertrieb and suitably Latinate or Greek-sounding ones such as automatisme ambulatoire, determinismo ambulatorio, dromomania, and poriomanie. ${ }^{1}$

[Młody człowiek miał na imię Albert; był pracownikiem okresowo zatrudnianym przez lokalną firmę paliwową, a także pierwszym uciekinierem. Cieszył się złą sławą za sprawą swoich niezwykłych wypraw do Algierii, Moskwy, Konstantynopola. Podróżował obsesyjnie, jak zaczarowany, często bez dokumentów, a niekiedy wręcz bez tożsamości, nie wiedząc, kim jest i dlaczego podróżuje, i wiedząc jedynie, do jakiego miejsca zmierza. Kiedy zaś tam przybył, miał niewielką świadomość odwiedzonych wcześniej miejsc, jednak pod wpływem hipnozy przypominał sobie utracone weekendy czy lata. [...]

Ucieczka przekształciła się w przypadłość medyczną na swoich własnych zasadach, zyskując nazwy takie, jak Wandertrieb, łacińsko lub grecko brzmiące automatisme ambulatoire, determinismo ambulatorio, dromomania i poriomanie.]

W roku 1887, kiedy doktor Philippe Tissie zapoznał się z kazusem Alberta Dadasa, człowieka tego potraktowano jako psychicznie chorego. Przypadków dromomanii z czasem było jednak coraz mniej i coraz trudniej było je klasyfikować czy diagnozować. Hacking pisze wręcz o fudze dysocjacyjnej jako o schorzeniu, którego prawie nigdy się nie orzeka, a jednak wciąż istnieje ono na listach Światowej Organizacji Zdrowia jako pewna diagnostyczna możliwość ${ }^{2}$. Polscy psychiatrzy zwracają uwagę na częstsze występowanie tej przypadłości w okresie wojen, katastrof i klęsk żywiołowych. Co ciekawe,

1 I. Hacking Mad Travelers: Reflections on the Reality of Transient Mental Illnesses, University Pres of Virginia, Charlottesville-London 1998, s. 7-8. W polskim piśmiennictwie psychiatrycznym nie posługujemy się pojęciem dromomanii, ale fugi dysocjacyjnej. Według klasyfikacji Amerykańskiego Towarzystwa Psychiatrycznego DSM-IV fuga dysocjacyjna zaliczona została w poczet zaburzeń dysocjacyjnych wraz z osobowością mnogą czy zespołem depersonalizacji i opatrzona numerem 300.13 (zob. Psychiatria, red. A. Bilikiewicz, S. Pużyński, J. Rybakowski, J. Wciórka, Urban \& Partner, Wrocław 2002, s. 490).

2 I. Hacking Mad Travelers..., s. 12. 
dromomania ujawnia się głównie u mężczyzn³ ${ }^{3}$ Jej przebieg, polegający na czasowej utracie pamięci i tożsamości, podporządkowanych przymusowi przemieszczania się, wydaje się niepokojąco przypominać awangardowe próby stworzenia nowej estetyki prędkości, w której zagubi się zarówno cel podróży, jak i - co może ważniejsze - dotychczasowa osobowość jednostki, zastępowana natychmiast innym, pozornie ustabilizowanym ja.

Oczywiście nie należy sądzić, że u artystów awangardowych powinno się diagnozować przypadek 300.13. Wydaje się jednak, że dromomania - jeśli dostrzeżemy w niej rodzaj shadow syndrome $e^{4}$ (syndromu nieostrego) - okaże się konsekwencją antropologicznej myśli awangardy wyrastającą z kataklizmów pierwszej połowy XX wieku: mierzącą się z doświadczeniem wielkiej katastrofy I wojny światowej i przeczuwającą nadejście kolejnej traumy; utrzymującą się w stanie nieustannego napięcia.

Paul Virilio, opisując narodziny nowoczesnego społeczeństwa, przywołuje obraz d ro m o m a n i a kó w, jakże bliski psychiatrycznemu syndromowi opisywanemu przez Iana Hackinga. Są oni bowiem nowoczesnymi żołnierzami, przemieszczającymi się kompulsywnie, kierowanymi nawet nie tyle logicznym rozkazem, ile samonapędzającym się rytmem wiecznej walki. W Prędkości i polityce czytamy:

przewodzenie bandami „zagubionych żołnieży” robotniczej armii - jej dromomaniakami - oznacza dla ich przywódcy spuszczenie ich z uwięzi, szczucie, podżeganie ich do ataku jak sforę psów [...]. Oznacza to rytmizację ruchu przemieszczających się nieustannie mas z użyciem metod prymitywnej stymulacji - transmitowaną wszędzie polemiczną symfonię, polifoniczną i wielobarwną, na wzór świetlnych znaków drogowych i kierunkowskazów, mających za zadanie przyspieszenie zdarzeń, wywołanie wstrząsu, doprowadzenie do wypadku. ${ }^{5}$

Zjawisko, które Virilio definiuje w kontekście ruchów rewolucyjnych i wojen ery nowoczesnej, można spróbować przenieść w domenę teorii społecznych rozwijanych w paradygmacie awangardowym. W myśl konstruktywistycznej wizji człowieka sfunkcjonalizowanego dostosowującego się do reguł

3 Psychiatria, s. 492.

4 Zob. J.J. Ratey Shadow Syndromes: The Mild Forms of Major Mental Disorders That Sabotage Us, Bantam Books, New York 1998.

5 P. Virilio Prędkość i polityka, przeł. S. Królak, Wydawnictwo Sic!, Warszawa 2008, s. 11-12. 
wyznaczanych przez zaprojektowaną przez „stalowego inżyniera" metropolię, jednostki zostają poddane właśnie owym inscenizowanym przesunięciom. Jeśli prześledzimy manifesty Władysława Strzemińskiego, zauważymy, że podstawową kategorią organizującą myślenie o przestrzeni jest właśnie ruch i jego kontrolowane przepływy. Warto jednak podkreślić, że są one zawsze podporządkowane pewnym stabilnym ideom i ich zadaniem nie jest - jak u Virilio - „spuszczenie z uwięzi” mas. W Zasadach nowej architektury Strzemiński pisze:

2) Celem architektury jest organizacja ry t $\mathrm{mu}$ kolejno po sobie następujących ruchów i przystanków, a przez to uformowanie całokształtu życia.

3) Ostatecznym celem architektury nie jest budowanie praktycznych domów [...]. Jej celem jest: być regulatorem rytmu życia społecznego i indywidualnego. ${ }^{6}$

Przestrzeń architektoniczna pełni więc w życiu człowieka funkcję porządkującą i stabilizującą ludzki pęd. Jednostka zostaje niejako „poruszona” przez nurt życia nowoczesnego i jednocześnie skazana na wykonywanie manewrów sterowanych czy też programowanych przez głównodowodzącego architekta. Szymon Syrkus wychodzi w Tempie architektury od problemu dynamizacji współczesnego myślenia o sztuce budowania, skupieniu na „biegu [...], w którym rozwijają się warunki socjalno-ekonomiczne"7 i jednocześnie proponuje własną strategię ich „łożyskowania”:

przez rozplanowanie miast, regulacje ruchu i komunikacji, przez usytuowanie osiedli, przez projektowanie domów, mieszkań [...] stwarza pewne łożyska i z m u s z a żyjących w nich ludzi do trybu życia, wynikającego z kierunku tych łożysk. ${ }^{8}$

Pozornie jesteśmy daleko od Viriliańskiego wyobrażenia rozpędzonej masy; wizualizujemy ją sobie bowiem jako coś niepohamowanego, dzikiego, nieposłusznego. Konstruktywiści dają nam tymczasem obraz społeczeństw

6 W. Strzemiński Zasady nowejarchitektury, w: tegoż Wybór pism estetycznych, oprac. G. Sztabiński, Universitas, Kraków 2006, s. 47.

7 Sz. Syrkus Tempo architektury „"Praesens” $1930 \mathrm{nr}$ 2, s. 3.

8 Tamże, s. 5 (wyróż. - M.K.) 
przykładnie poddających się władzy „organizatora ruchu”. Wizja z Prędkości i polityki do takiego obrazu nas jednak właśnie prowadzi: tyle, że przedstawia go niejako w wersji skrajnej. Virilio także opisuje panujących nad dromomaniakami rozkazodawców, którzy używając „metod prymitywnej stymulacji”, kierują procesem ich przemieszczania się. Dążą jednak - wbrew manifestowanej przez funkcjonalistów idei - do osiągnięcia gwałtownego przyspieszenia. Zarówno Strzemiński, jak i Syrkus opowiadają się zaś po stronie prędkości „opanowanej z zewnątrz”, wtłoczonej w określone miejsca, nasycającej je i służącej podniesieniu wydajności pracy. Viriliańscy dromomaniacy zostają zatem poddani analogicznemu procesowi o przeciwstawnym wektorze: mają podporządkować się dowódcy, który będzie napędzał ich do coraz szybszego parcia naprzód. Ich pęd zostanie złożyskowany w działanie rewolucyjne.

Bliższe opisom przemarszów dromomaniaków z tekstów Virilio są z pewnością archetypiczne dla awangardy wizje futurystyczne. W Akcie założycielskim i manifeście futuryzmu czytamy:

Wsłuchując się jednak w słabiutki modlitewny szmer starego kanału, w trzeszczenie kości umierających pałaców, obrosłych wilgotną zielenią, usłyszeliśmy nagle pod oknami ryk zgłodniałych automobili.

Chodźmy, rzekłem, chodźmy przyjaciele! Ruszajmy! [...] Trzeba będzie wstrząsnąć bramami życia, aby wypróbować ich zamki i zawiasy! Ruszajmy! [...]

Zbliżyliśmy się do trzech parskających bestii, aby pomacać miłośnie ich gorące piersi. Wyciągnąłem się w mojej maszynie jak trup w trumnie, lecz ożyłem natychmiast pod kierownicą, ostrzem gilotyny zawieszonym nad moim żołądkiem.

Potężna miotła szaleństwa oderwała nas od nas samych rzucając w ulice urwiste i głębokie jak łożyska strumieni. ${ }^{9}$

Marinetti zaczyna od opisu zamierającego świata, z którego powoli i w ciszy ulatnia się życie. Owa kruszejąca rzeczywistość zostaje ostatecznie pokonana czy wyparta przez hałas silnika samochodowego. Skrajnie ekspresjonistyczny styl „aktu założycielskiego", zasadzający się na hiperboli, kontraście, wykrzyknieniach, wprowadza nas w atmosferę nadmiaru, przesady. Automobil z 1909

9 F.T. Marinetti Aktzałożycielski i manifest futuryzmu, przeł. M. Czerwiński, w: Artyści o sztuce. Od van Gogha do Picassa, oprac. E. Grabska, H. Morawska, PWN, Warszawa 1969, s. 140-141. 
roku nie osiąga może radykalnych prędkości, ale z całą pewnością odmienia dla włoskiego futurysty doświadczenie świata zewnętrznego. Ma wywołać wstrząs, rozbić bramy kontrolujące przepływy ruchu. Posadzenie człowieka za kierownicą samochodu to moment Viriliańskiego "spuszczenia z uwięzi”: obietnica wolności wynikającej z kompulsywnego przemieszczania się. Zerwanie więzi ze wszystkim tym, co statyczne, okazuje się też przekroczeniem własnej śmierci, zmartwychwstaniem. Unieruchomienie trupa przeistacza się w żywotność jednostki wystawionej na ekstremalne doświadczenia (gilotyna ciągle unosi się nad jego brzuchem). Marinetti, poddając się władzy maszyny, traci osobowość, zyskuje zaś płynną tożsamość: nieprzerwanie zmienia się z bestii w młodego lwa, kochanka, szaleńca, „łachman śmierdzący i brudny”10. Odrywa się od siebie i dryfuje już pozbawiony zakorzenienia w intersubiektywności, wyzwolony z okowów rozsądku i własnej woli.

Współistnienie z maszyną prowadzi go jednak - na wzór Viriliańskich dromomaniaków - do katastrofy. W zderzeniu z dwójką cyklistów wpada do rowu:

O! Macierzysty rowie, niemal wypełniony błotnistą wodą! Piękny rowie fabryczny! Smakowałem twoją wzmacniającą papkę, która mi przypominała świętą czarną pierś mej sudańskiej mamki... Kiedy się podniosłem łachman śmierdzący i brudny - spod wywróconej maszyny, poczułem jak przeszywa mi serce w rozkoszy rozżarzone żelazo radości."

Nieograniczone przyspieszenie, którego nie kontroluje już żadne „ja” (ono bowiem rozkłada się i rozpada wraz z narastaniem szybkości), wiedzie ku śmierci i ostatecznej zagładzie wszelkiej podmiotowości. Jednocześnie u Marinettiego właśnie ze zgliszcz powstaje człowiek nowy, podporządkowany idei witalizmu technologicznego, odarty z własnej tożsamości i przejmujący świadomość maszyny. Człowiek skazany na wieczne parcie przed siebie, zatracony we własnym ruchu, uzależniony od konieczności przemieszczania się. On zatem wypowiada hasła pierwszego manifestu futurystycznego:

4. Oświadczamy, że wspaniałość świata wzbogaciła się o nowe piękno: piękno szybkości! Samochód wyścigowy ze swoim pudłem zdobnym

\footnotetext{
10 Tamże, s. 142.

11 Tamże.
} 
w wielkie rury podobne do wężów o ognistym oddechu... ryczący samochód, który zdaje się pędzić po taśmie karabinu maszynowego, jest piękniejszy od Nike z Samotraki.

5. Chcemy opiewać człowieka dzierżącego kierownicę, której oś idealna przeszywa Ziemię, ciśniętą także w bieg po swej orbicie. ${ }^{12}$

Bohaterem nowoczesnej poezji staje się więc spojony ze swoim automobilem kierowca ${ }^{13}$ : to jego perspektywa okazuje się najbardziej interesująca. Zastępuje on tradycyjne dzieło i sam staje się ekranem dla rozgrywającego się spektaklu świata. Futuryści nie próbują już tworzyć artefaktu będącego mimetyczną reprezentacją rzeczywistości: powołują do życia dzieło, które samo jest prędkością; tworzą utopię aeropoezji, sztuki wiecznie przyspieszającej, efemerycznej, zanikającej, uwolnionej od konieczności konstruowania stabilnego sensu. Ich pęd jest więc w oczywisty sposób pędem ku samozagładzie, rozproszeniu się wśród napływających obrazów i odbić. Realizują oni założenia dromologicznej rewolucji, która anuluje nawet swoją własną postępowość: nie chodzi jej bowiem o zatrzymanie czy zachowanie osiągnięć technicznych, społecznych lub politycznych, ale o ich nieustanne przezwyciężanie ${ }^{14}$.

W tym miejscu możemy zaobserwować rozchodzące się drogi ruchów futurystycznego i konstruktywistycznego: choć oba apoteozują ruch, który należy w jakiś sposób wykorzystać, prowadzą nas one do przeciwstawnych rozwiązań. Owo rozszczepienie (widoczne już w paradygmacie awangardowym) dostrzega też Virilio, tworząc podział na rewolucję handlową, która „dążyła do wzbogacenia się na drodze akumulacji «ruchów» (działań)

F.T. Marinetti Akt założycielski..., s. 142-143.

Kierowca i jego spojrzenie uchodzi za swoisty topos literatury nowoczesnej. Problem wytwarzania się "systemu automobilnego" z perspektywy socjologicznej analizuje John Urry w artykule The System of Automobility, "Theory, Culture, and Society" 2004 No. 4/5, s. 25-39.

W ten sposób dromologię opisuje Marc Hanes: "Modern progres has not been defeated by its relativist enemies: progres has destroyed itself by fulfilling its goal only too well, i.e. by improving its technological abilities until those abilities went beyond any effective control" [Nowoczesny postęp nie został pokonany przez swoich relatywistycznych wrogów; sam siebie zniszczył realizując swoje cele aż za dobrze, np. poprzez poprawę swoich technologicznych możliwości do tego stopnia, że nie mógł ich już dłużej kontrolować] (M. Hanes Paul Virilio and

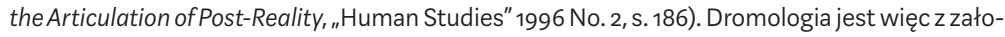
żenia - podobnie jak awangarda - nauką dążącą do samozaprzeczenia, nieustannego negowania własnych osiągnięć, wpatrującą się we własną katastrofę. 
wytwórczych" (przypadek konstruktywizmu), i wojskową, kapitalizującą "niszczycielskie działania mobilnej masy” i wytwarzającej zniszczenia (przypadek futuryzmu) ${ }^{15}$.

Do ich ciekawego sprzężenia dochodzi w poezji Juliana Przybosia. O ile w myśli teoretycznej twórcy nie pojawia się taki rodzaj łożyskowania ludzkiej aktywności, jaki możemy obserwować w tekstach Virilio poświęconych wojnie czy u futurystów, o tyle w liryce z tomów Śruby, Oburącz czy Z ponad wydaje się on aż nadreprezentowany. Wpływy ekspresjonistyczne i futurystyczne, odciskające niewątpliwe piętno na tych pierwszych tomach, dają o sobie znać w obrazach niepohamowanego pędu, niemożliwych do zatrzymania w swej (często prowadzącej do absurdu) pracy robotników, nieustannych przepływach tłumów, parciu wzwyż i naprzód.

Wczesne wiersze Przybosia, czytane dotychczas raczej jako reprezentacja konstruktywistycznych postulatów kontrolowanego progresu ${ }^{16}$, powinno się zatem zestawiać także z archetypicznymi wizjami futurystów: tylko wówczas będziemy mogli uchwycić ich podwójność w rozumieniu ruchu. Zobaczymy również, że ekspresjonizm nie jest tutaj spuścizną po poprzedniej epoce staje się raczej, podobnie jak w Akcie zatożycielskim futuryzmu, wyrazem nowej estetyki prędkości, nadmiaru docierających do podmiotu bodźców, doświadczeń percepcyjnych i zmysłowych.

\section{Dromoskopia}

Awangardowy kult szybkości odsyła nas w pole znaczeniowe nie tylko takich zjawisk, jak dromomania. Właściwie możemy zaryzykować tezę, że przymus ruchu jest tylko wstępną fazą rozwoju swoiście rozumianej d ro mo s ko p ow ej poetyki. Pozwala on bowiem dookreślić egzystencjalną sytuację nowoczesnego człowieka poddanego dyktaturze motorycznej (wywołanej z jednej strony pojawieniem się nowych czy ulepszonych środków transportu, ale także wywodzącej się z głęboko zakorzenionego przekonania, że wszelki ruch jest życiem i gwarantem rozwoju), nie wystarcza jednak, by scharakteryzować odbicie owej manii w obrębie podejmowanej przez niego działalności

15 P. Virilio Prędkość..., s. 44.

16 Zob. E. Rybicka Modernizowanie miasta. Zarys problematyki urbanistycznej w nowoczesnej literaturze polskiej, Universitas, Kraków 2003, s. 228-253; B. Sienkiewicz Poznawanie i nazywanie. Refleksja cywilizacyjna i epistemologiczna w polskiej poezji modernistycznej, Universitas, Kraków 2007, s. 321-396. 
artystycznej. Aby opisać przemiany percepcji i tworzonego na podstawie doświadczenia niepohamowanego ruchu światoobrazu, wydaje się, że warto przywołać kolejną z Viriliańskich kategorii: d r o m o s k o p i ę ${ }^{17}$,

Do czego odnosi się ta kategoria w uniwersum Virilia? Najogólniej rzecz ujmując, dromoskopia stanowi rewers stroboskopii:

Opposite to stroboscopy which allows us to observe object animated by rapid movement, as if they were in slow motion, this dromoscopy displays inanimate objects as if they were animated by a violent movement. ${ }^{18}$ [W przeciwieństwie do stroboskopii, która pozwala na obserwację poruszającego się z dużą szybkością obiektu jak gdyby w zwolnieniu, dromoskopia prezentuje nieruchomy obiekt tak, jak gdyby był poddany gwałtownemu poruszeniu.]

Ta podstawowa konstatacja ma co najmniej dwie konsekwencje. Po pierwsze, wprowadza kategorię, której zadaniem jest opisanie pewnego charakterystycznego sposobu postrzegania rzeczywistości. Człowiek, znajdujący się w ruchu, zaczyna inaczej widzieć statyczne obiekty, z jakimi się styka. Nie tylko przestają one być nieruchome, ale kreują także nowy rodzaj zależności między patrzącym „ja" i - dotychczas wydawałoby się stabilnym - światem zewnętrznym. Po drugie, dromoskopia ustanawia nowy rodzaj sztuki, nazywany przez Virilio „sztuką deski rozdzielczej”"'. Jednostka w ruchu kreuje dla siebie nową przestrzeń wypełnioną obiektami o zacierających się granicach, nieobecnymi w swoich własnych ramach i tym samym wkraczającymi w domenę symulakrów.

W swoim eseju Virilio opisuje dromoskopię jako doświadczenie właściwe kierowcom samochodów; to oni stają się dla niego artystami nowej ery, uzależnionymi od coraz większego przyspieszenia. Viriliański kierowca jest

17 W dotychczasowych badaniach, aby opisać "ruchomość" spojrzenia podmiotu awangardowych tekstów, używano raczej instrumentarium pojęciowego związanego z techniką filmową. Zob. m.in. Cinema and the Invention of Modern Life, ed. by L. Charney, V.R. Schwartz, University of California Press, Berkeley 1994; The Image in Dispute: Art and Cinema in the Age of Photography, ed. by A Dudley, University of Texas Press, Austin 1997; J. Chatlos Automobility and Lyric Poetry: The Mobile Gaze in William Carlos Williams ', The Right of Way", ",Journal of Modern Literature" 2006 No. 1, s. 140-154.

18 P. Virilio Negative Horizon. An Essay in Dromoscopy, przeł. M. Degener, Continuum, LondonNew York 2008, s. 101 
jednocześnie reżyserem, aktorem i widzem spektaklu szybkości. Podróżnik-obserwator okazuje się zarazem tym, który sam wyświetla się na przedniej szybie: obserwuje nie tyle mijany krajobraz, ile siebie samego, przemykającego drogą. Szyba staje się w powstałym układzie „symulatorem krajobra$\mathrm{zu}^{\text {"20 }}$, a nie przezroczystą barierą, która pozwala go oglądać. Rzeczywistość dematerializuje się, znika, w jej miejsce zaś wkracza reprezentacja realności, jej sfabrykowana przez postrzegający podmiot wersja.

Negative Horizon wyznacza zatem nowe pole refleksji społeczno-antropologicznej: Virilio bierze tam na warsztat postać nowoczesnego człowieka poruszanego mocą maszyny, wchodzącego z nią w nierozerwalną fuzję, którego los (i historia: nie zapominajmy, że dromoskopia prowadzi nas w stronę dromokratycznych wojen) zależy od percepcyjnych zmian wywołanych przez owo splecenie. To dziwne, że właściwie w ogóle nie wspomina on w swoich rozważaniach o jakichkolwiek inspiracjach awangardowych. Oczywiste wydaje się bowiem, że sztuka eksperymentalna początku wieku zawiera w sobie wszelkie składniki dromoskopowego postrzegania: zaburza się w niej opozycja wnętrze - zewnętrze, obiekty nieruchome zostają włączone w korowód wiecznego pędu ku przyszłości, zanika punkt zbieżny perspektywy (jak w malarstwie Strzemińskiego czy wierszach Przybosia, gdzie zostaje on wyparty przez sekwencję ruchomych spojrzeñ ${ }^{21}$ ), świat jawi się podmiotowi w swoim przepływie, obrazy przemieszczają się, przesuwają przed oczami niczym taśma filmowa, są efemeryczne, podzielone na pojedyncze klatki. Artystów zaczyna interesować przede wszystkim to, co rozpościera się na horyzoncie, w przyszłości. Punkt dojścia staje się tak istotny, że wypiera właściwie cały proces podróżowania: mamy wrażenie, że przestrzeń kurczy się i składa już tylko z projekcji tego, co nastąpi, neguje teraźniejszość. Schematy wyprzedzania czasu (charakterystyczne dla poetów awangardy krakowskiej), symultanicznej obecności w wielu punktach docelowych (jak w zwielokrotnionych przez język przestrzeniach namopaników Wata), rozszczepiania

20 Tamże, s. 103.

21 Zob. „Perspektywa zbieżna wychodzi z założenia, że jednym nieruchomym spojrzeniem równomiernie ogarniamy całe pole widzenia. Patrzymy w punkt zbiegu i wówczas widzimy obraz świata. To odpowiadałoby matematyce, lecz nie odpowiada rzeczywistości naszego widzenia. Nigdy nie patrzymy na świat jednym spojrzeniem nieruchomym. Nasze widzenie świata składa się ze spojrzeń ruchomych. Patrzymy kolejno na rozmaite przedmioty, rzucamy spojrzenia w różnych kierunkach, i dopiero z podsumowania ich przez uświadamiającą myśl powstaje jednolity obraz widzianej rzeczywistości". (W. Strzemiński [Perspektywa a widzenie ruchome], Wybór..., s. 189). 
się rzeczywistości i anulowania czasowego postrzegania w poezji surrealistycznej czy tworzenia literatury futurologicznej, prezentującej rozwiązania przyszłości (obecne właściwie w każdym awangardowym ruchu; w Polsce widoczne choćby w dystopijnej wizji z Palę Paryż Jasieńskiego) - wszystkie te strategie podyktowane są z jednej strony - maniakalną potrzebą ruchu i depersonalizacji właściwą dromomanii, z drugiej zaś - prymatem dromoskopowego, poddanego presji motorycznej poznania.

\section{Tekst dromoskopowy}

Warto więc powołać do istnienia kategorię nową, której sam Virilio nie stosuje, gdyż nie poddaje interpretacji tekstów kultury. Przesunięcie jego antropologicznych rozważań o dromoskopii w pole literaturoznawstwa pozwala na uformowanie terminu tekst dromoskopowy. Czym jednak miałby być ów tekst? I dlaczego nie wystarczy opisać go za pomocą pojęć związanych z ruchem, postępem czy przemieszczaniem się?

Tekst dromoskopowy w pewnym sensie wchłania w siebie wiele kategorii, które w dotychczasowych badaniach nad awangardą były rozproszone. Używając jednego tylko, pożyczonego od Virilia i poddanego redefinicji, terminu moglibyśmy opisać złożony przebieg procesów percepcyjnych, które wynikają nie tylko z samego "uruchomienia podmiotu”, ale łączą się także ze zjawiskiem od-tożsamienia, utraty stabilnej formy (zarówno dla świata, jak i dla siebie), kreowania przestrzeni nieistniejącej, symulakrycznej, wyobrażenia człowieka-projektora, który nie tyle doświadcza, ile od razu rzutuje swoje doświadczenie na rzeczywistość, wprowadzając w nią swoiste modyfikacje. Jednocześnie pozwala on światu zewnętrznemu wchodzić ze sobą w kolizję. Dromoskopia okaże się tym samym poręcznym terminem na opisanie granicy między tym, co zwykliśmy określać mianem poetyki konstruktywistycznej (ukierunkowanej na tworzenie i przekształcanie realności, jej programowanie) a strategiami poetyki percepcyjnej (skupionej na odnotowywaniu wrażeń faktycznie doświadczanych) ${ }^{22}$.

Najlepiej więc prześledzić owo pojęcie w działaniu na przykładzie utworów powstających właśnie w czasie „przełomowym”: w chwili narodzin nowego języka artystycznego, wykluwania się prawdziwie awangardowej koncepcji metafory. Takim momentem będzie dla mnie rok 1930 w twórczości

22 O różnicy między poetyką konstruktywistyczną i percepcyjną zob. E. Rybicka, Modernizowanie..., s. 100-180, 228-253. 
Juliana Przybosia. Autor Równiania serca żegna się wówczas z - nieco przebrzmiałą i z pewnością nie w pełni przemyślaną - poetyką dwóch pierwszych tomów (Śruby i Oburacz), wciąż jednak pozostaje pod bardzo mocnym wpływem myśli konstruktywistycznej. Koniec lat 20. to przecież czas, kiedy Przyboś aktywnie uczestniczy w działaniach grupy „,a.r.", tworzy podwaliny jej programu „ekonomizacji literatury” i nadawania sztuce charakteru funkcjonalnego. Właśnie wtedy podejmuje wraz z Władysławem Strzemińskim próbę wydania swojej książki $Z$ ponad zgodnie z zasadami druku funkcjonalnego. $\mathrm{Na}$ tym przykładzie - układów z wydanego w 1930 roku tomiku - chciałabym zaprezentować ideę tekstu dromoskopowego.

Z ponad możemy bowiem uważać za pierwszą fazę zmiany, jaka dokonuje się w pisarstwie Przybosia: o ile w Oburącz jeszcze mieliśmy do czynienia z mocną siatką porządkujących pionów i poziomów oraz z - górującą nad światem - postacią "stalowego inżyniera” ${ }^{23}$, o tyle w 1930 poeta odchodzi już od tak mocno zarysowanej inspiracji konstruktywizem, zbliżając się tym samym do - osiągających apogeum w Równaniu serca - zapisów doświadczeń wzrokowych. Pisząc o Z ponad kilka lat temu, stawiałam tezę o postgeometryczności prezentowanego tam świata. Miasto nie wyzwoliło się jeszcze spod wpływu konstruktywizmu, nie podlegało jednak bezrefleksyjnie jego założeniom ${ }^{24}$. Obserwujemy więc sytuację, w której w wierszach znajduje się wciąż sporo śladów fascynacji geometrycznością, kątem prostym, urbanistyką funkcjonalną, ideą budowy, wizją poety jako "robotnika słowa”. W Gmachach czytamy o "dwurzędzie bloków”, „poecie - wykrzykniku ulicy”, „murach - wynikłych ściśle”25. W Murarzach znajdziemy charakterystyczny obraz zespolenia człowieka i budynku: „waszemi pięściami nabity każdy kamień"26. Jednocześnie, ruch coraz częściej nie ma już - jak w niegdysiejszych Dachach - charakteru progresywnego. Wiersz ze Śrub był bowiem podporządkowany w całości idei wspinania się, na coraz wyższe poziomy społeczno-ekonomicznego rozwoju:

23 J. Przyboś, Rezolucja, w: tegoż Utwory poetyckie, t. 1, oprac. R. Skręt, Wydawnictwo Literackie, Kraków 1984, s. 42.

Zob. M. Kmiecik Oblicza miejsca. Topiczne i atopiczne wyobrażenia przestrzeni w poezji Juliana Przybosia, Universitas, Kraków 2013, s. 138-153.

J. Przyboś Z ponad, ułożył graficznie W. Strzemiński, Zakłady Drukarskie i Wydawnicze Karola Prochaski, Cieszyn 1930, s. 15. 
Wyżej!

$[\ldots]$

W żywym patosie konstrukcji, w geometrycznym wymiarze wspina się, urastając, sześcienna dusza stolic.

Warczy windami rozmachu, zawisa na lewarze, wskoczy! Na wieżach radia z materii myśl wyzwoli. ${ }^{27}$

Rozpoczynające go zawołanie miało za zadanie natchnąć człowieka do pracy: budowania nowej rzeczywistości, tworzenia monumentalnych gmachów, z wierzchołków których ludzkość będzie mogła spokojnie obserwować ogrom swojego dzieła. Przyboś w pierwszych tomach faktycznie pozostaje niewolnikiem konstruktywistycznej wyobraźni; inspirowany nią, pragnie ujrzeć poetę-budowniczego wyniesionego ponad miasto, stojącego - niczym obserwator w Praktykach przestrzennych de Certeau ${ }^{28}$ - w oddaleniu, zawłaszczającego świat własnym spojrzeniem. Ruch zawsze ma tutaj cel, jest, jak pisze Barbara Sienkiewicz, konieczny:

"dusza stolic" wyzwala z materii myśl konstrukcyjną, figurotwórczą.

Zapewne takie ujęcie lepiej oddawało swego rodzaju konieczność, nieuniknioność przekształceń, nieuchronność konstruowania, które jako idea, zgodnie z przeświadczeniem Peipera, wpisane jest w życie społeczne, w drogę kultury, która jest oddalaniem się od natury. Takie są prawa postępu i musi się on dokonać. ${ }^{29}$

Wszelkie pojawiające się w wierszu „płaszczyzny wznoszące” zbliżają nas do uformowania „sześciennej duszy stolic”. Jak jednak słusznie zauważa Sienkiewicz, Przybosiowe spełnienie okazuje się wyjściem z materii ku myśli wyzwolonej: abstrakcyjnej idei. Postęp wydaje się tu z jednej strony podporządkowany kulturowemu narastaniu i akumulacji wiedzy i „działań wytwórczych" (zgodnie z ekonomiczną zasadą Viriliańskiej dromologii), z drugiej jednak prowadzi nas ku wizji katastrofy właściwej praktykom dromomaniaków:

27

28

J. Przyboś, Utwory..., s. 6.

Zob. M. de Certeau Praktyki przestrzenne, w: tegoż Wynaleźć codzienność. Sztuki działania, przeł. K. Thiel-Jańczuk, Wydawnictwo Uniwersytetu Jagiellońskiego, Kraków 2008, s. 93-94.

B. Sienkiewicz, Poznawanie i nazywanie..., s. 325. 
Jak elektryczność błyśnie, podskoczy murem w górę, przestworem napęcznieje olbrzymi miasta kolos; rozniesie wszystkie place, rozsadzi mas strukturę, wypnie, jak lane przęsło, nieskończoności koło.

Ruch podmiotu opętanego manią progresywnego i przyspieszającego ruchu („Sztabami ramion roztrącę ulic gardła” - pisze w pewnym momencie) prowadzi ku nadprodukcji wrażeń: metropolia nie jest już w stanie pomieścić w sobie wytworzonej przez prędkość energii. Jej kumulacja prowadzi więc do „wielkiego wybuchu”, w wyniku którego - zupełnie jak w manifeście Marinettiego - rodzi się nowy świat i nowe, lepsze ja. Owo "rozsadzenie struktury” z tekstu Przybosia prowadzi do zaniku granicy między konstruktorem a rzeczywistością, utraty cech osobowych. Virilio w Dromoscopy dostrzega ten moment przejścia właśnie w chwili katastrofy. Pisze:

when the illusion comes to its brutally violent cessation in a collision, it is as if the voyeurs-voyagers are projected like Alice through the looking glass windshield, a death jump but above all a jump into the truth of their trajectory where the gap between the theatre hall and the stage collapses, the spectators becoming actors: it is this fleeting insurrection that the seat belt is designed to prevent. ${ }^{30}$

[kiedy iluzja zostaje brutalnie wstrzymana w czasie kolizji, dochodzi do sytuacji, w której podróżnicy-obserwatorzy są rzutowani niczym Alicja na lustro przedniej szyby pojazdu. Jest to śmiertelny skok, ale umożliwia on wskoczenie na właściwą trajektorię, gdzie przestrzeń między sceną a salą załamuje się, a widzowie stają się aktorami: jest to krótkotrwałe powstanie, któremu miał zapobiegać pas bezpieczeństwa.]

Wypadanie kierowcy przez przednią szybę auta, która dotychczas pełniła funkcję ekranu wyświetlającego symulakryczną przestrzeń, jest jego wpadaniem w rzeczywistość, przekraczaniem granicy między tym, co skonstruowane przez jego umysł (projekcją: u Przybosia, projekcją „sześciennej duszy”), a tym, co prawdziwe (nieustannie przetwarzanym światem zewnętrznym). Miasto geometryczne ustępuje w owej kolizji miejsca miastu niemożliwemu do opanowania, wchłaniającemu czy wręcz pożerającemu ludzką jednostkę. 
Nagle podmiot przestaje tylko obserwować zaprogramowany przez siebie spektakl; zgodnie z ideą dromoskopii Virilia wykracza poza rolę reżysera-widza i zostaje zmuszony do wzięcia udziału w rozgrywającym się przedstawieniu. Staje się jego budulcem (niczym w słynnych Cieślach z tomu Śruby) i stapia się ze światem przez siebie tworzonym (podobnie jak Józef Rąb, bohater wiersza Porwany przez przenośnię). Zniesienie granicy między potrzegającym podmiotem a przedmiotem obserwowanym dokonuje się już więc w dwóch pierwszych zbiorach: zawsze jednak podporządkowuje się jakieś nadrzędnej instancji. Ruch zostaje niejako wtłoczony w maszynę, napędza jej koła zębate. W Perpetuum mobile czytamy:

W rwącej szybkości prącej szybkości

Obroty koła obręcze kół

Suwaki ustawiczne i składne

Obracające się koła

Obracające się koła

Dystanse dalekonośne

Koła $^{31}$

Prędkość napędza obroty kół; obroty, co ważne „ustawiczne i składne”. Napięcie, oczekiwanie na katastrofę, pozostaje u Przybosia złagodzone. Dopiero w Z ponad spróbuje on wyprowadzić je na granice percepcyjnej wytrzymałości. Zradykalizuje gwałtownie swoją poetykę: zacznie unikać regularnego, hymnicznego wręcz wersu, ekonomizować środki wyrazu po to, aby wywołać jeszcze większe poczucie naprężenia rzeczywistości, jej zawieszenia w stanie tuż przed wypadkiem. Notowanie przygód percepcyjnych i coraz głębsze poczucie wymykania się przestrzeni, której nie sposób już unieruchomić czy odpowiednio złożyskować, ujawni się najpełniej w wierszach poświęconych przemieszczaniu się, gdzie podróż okazuje się - jak w eseju Virilia - punktem wyjścia antropologicznej refleksji.

Skupmy się na wierszu bardzo dobrze znanym i wielokrotnie komentowanym, który stał się w pewnym sensie lirycznym manifestem awangardowej poetyki Przybosia: Na kołach. Chciałabym - aby uwypuklić różnicę między tekstem o ruchu (tematyzującym ruch) a tekstem dromoskopowym - zestawić go z wcześniejszą próbą ze Śrub - utworem Na uskrzydlonych kołach. Już

31 J. Przyboś Utwory..., s. 16. 
same tytuły wskazują na pewne powiniwactwa między obiema realizacjami. Zupełnie jakby Przyboś drugi raz podchodził do tego samego zagadnienia: odejmując mu jednak swoistą wzniosłość. Znika poczucie „uskrzydlenia”, wyjątkowości, zastąpione suchym i jakże konkretnym wskazaniem: wiersz potoczy się dziś na kołach przed oczami odbiorcy.

Tekst ze Śrub już od samego początku przypomina hymn ku czci nowoczesności:

Na uskrzydlonych kołach w pęd wprawieni potężny, ku rozpostartej dali szturmem dróg niebosiężnych prąc w niewstrzymanym trudzie, twardzi i ustawiczni jedziemy poruszani oddechem mechanicznym. ${ }^{32}$

Znajdziemy tutaj wszystkie toposy modernizacyjne: pęd, trud pracy, konsekwencję i „stalowość" poglądów czy postaw, sprzężenie z maszyną. W dodatku tekst pisany jest czternastozgłoskowcem o stałym, wybijającym się rytmie. Instrumentacja oparta na głoskach $\dot{z}$ i $r$ wprowadza nas w nastrój podniosły, ale także nadaje wierszowi swoistej szorstkości prędkości: czytamy go potoczyście, głośno. Tekst ten niewątpliwie mówi bowiem o potrzebie podróżowania bez przystanków, coraz bardziej zaawansowanymi środkami transportu (przechodzimy od kolei przez samolot, statek, następnie zaś podmiot mówi już o podróżowaniu po kablach telegraficznych). Moglibyśmy więc założyć, że Na uskrzydlonych kołach mieści się w ramach naszkicowanej póki co pobieżnie kategorii tekstu dromoskopowego.

Wydaje mi się jednak, że - owszem - prezentuje on nam jednostkę dromomaniakalną, kompulsywnie uciekającą, zmierzającą do intensyfikacji swoich podróżniczych przeżyć, zatracającą się w nich i rezygnującą ze swojej ludzkiej tożsamości. Wiersz kończy bowiem strofa zapowiadająca rozszczepienie człowieka:

Wyprężonym szeregiem, rąk złączywszy ogniwa, skuci wolą płomienną natchnionego porywu popłyniemy napięci w prąd radosnej energii:

przemienieni w promienie, skry, ampery i ergi. ${ }^{33}$ 
Rozpędzona jednostka zostaje tutaj rozbita niczym atom: staje się czystą energią. Nie ma już świadomości, która mogłaby wziąć odpowiedzialność za własny ruch, podmiot - podobnie jak w komentowanym wcześniej syndromie psychiatrycznym - traci pamięć o sobie samym: o tym, kim jest i po co się przemieszcza. Ruch odbywa się poza tożsamością.

Ta wyjściowa sytuacja dromomaniakalna nie wchodzi jednak w fazę dromoskopowego zapisu. Doświadczenie odpodmiotowienia i nienaturalnego przyspieszenia teoretycznie mogłoby ją wywołać, ale w pierwszej z prób Przybosia to się nie udaje. Sama fascynacja szybkością i przywołanie związanego $\mathrm{z}$ nią imaginarium nie wystarcza. Zyskujemy wiersz tematyzujący prędkość, ale nie utwór, który sam jest prędkością. Owszem, Przyboś próbuje jakoś zanotować zmieniającą się percepcję; nie potrafi jednak stworzyć skondensowanej metafory:

W hali wzniesionych niebios, dudniącej metalicznie, zapalamy oczami słońca lamp elektrycznych.

Pięści wznosimy w górę jak raptowne sygnały, dzwoniąc, giną wiadukty, wzdłuż nagle się urwały.

Wsie kładą się pokotem jak progi popod koła.

[...]

Wartkim galopem słupów rwąc kilometry drogi, kir tętniącej przestrzeni podścieliwszy pod nogi, wpadniemy jednym rzutem w grzmocie żelaznych kroków w miasto wzniecone nagle jak pożoga wśród mroków. ${ }^{34}$

Człowiek nie wyświetla sobie tutaj krajobrazu przed oczami, nie fragmentaryzuje go, a jedynie dynamizuje i podporządkowuje swojej pędzącej maszynie. Właściwie możemy raczej mówić o zostawianiu świata zewnętrznego w tyle i uśmiercaniu go (stąd liczne obrazy „podkładania się” go pod koła, rozkładania się na szynach). Podmiot całkowicie zawłaszcza rzeczywistość, panuje nad nią: to on przecież „zapala oczami" lampy, to on „wznieca” miasto przed sobą. Cały czas sytuuje siebie w pozycji dowodzącego spektaklem reżysera.

Przyboś zbliża się w ten sposób coraz bardziej do wizji Viriliańskiej: nie udaje mu się jednak zrobić jednej rzeczy - przekroczyć granicy między tym, co reżyserowane i tym, co gwałtownie doświadczone. Innymi słowy, nie udaje mu się wypaść przez przednią szybę własnego pojazdu i zderzyć się 
z iluzorycznością wytwarzanej nieustannie projekcji. Wszystko, co widzimy w Na uskrzydlonych kołach, zostaje niejako "uskrzydlone" siłą wyobraźni, zmyślone. Tekst dromoskopowy nie tyle zaś poprzestaje na konstatacji, że pęd stwarza rzeczywistość symulakryczną. Próbuje on własnym „ciałem” się $\mathrm{z}$ niej wydobyć.

Na kołach ze Z ponad wydaje mi się właśnie taką próbą. Jej dromoskopowość zostaje dodatkowo wzmocniona przez graficzny układ Strzemińskiego, który gwarantuje i potwierdza istnienie wiersza w wierszu ${ }^{35}$ : jakiegoś innego, obcego obiektu wkraczającego w przestrzeń lirycznego zwierzenia. Utwór posiada bowiem - uwypukloną graficznie - ramę modalną. Dwa pytania retoryczne okalające wiersz stwarzają między sobą pustą przestrzeń: w niej właśnie ma się uobecnić utopijny ze swej natury tekst dromoskopowy. Warto zatem na początku zastanowić się nad ich znaczeniem. Otwarcie - „Jak swój dzień wywieść z obiegu?"36 - jest właśnie pytaniem o możliwość wydostania się z zaklętego kręgu symulakrów percepcyjnych. Chcąc tego dokonać, należy nie tyle przełamać ruch okrężny, ile wydostać się z maszyny, która wiezie nas nieustannie dostępnymi ścieżkami: uruchomić siebie, a nie akceptować własną nieruchomość w ruchomym obiekcie. Wypaść więc przez przednią szybę, aby doświadczyć tego, co nie jest już tworzoną dla nas iluzją? Wówczas właśnie to nie my potoczymy się na kołach auta, ale tekst potoczy się na kołach własnych, sam stanie się prędkością, a nie tylko rejestratorem pędu.

Przyboś, tworząc ramę dla wiersza, z pewnością nawiązuje do awangardowej utopii uobecnienia tekstu jako realnego bytu, materializacji literatury. Chce, aby liryk nie tylko został zapisany, ale działał bezpośrednio na odbiorcę, dając mu poczucie uczestnictwa w rzeczywistości przedstawionej. Właściwie próby stworzenia tekstu dromoskopowego (czy będzie to aeropoemat futurystyczny, czy Przybosiowy „,wiersz uruchomiony”) stają się tym samym próbami wykroczenia poza obieg literatury: chcą na nowo zrównać sztukę z praktyką życiową, nie kreować świata, ale go - bez nanoszenia zmian czy poprawek - przenieść do dzieła. Nie bez powodu Strzemiński tłumaczył

35 W interpretacji Ireny Urbaniak wszystkie układy Strzemińskiego służą „podziałowi tekstu na poszczególnie części znaczeniowe” (I. Urbaniak Analiza zgodności znaczeniowo-graficznej „Sponad" Juliana Przybosia w opracowaniu typograficznym Władysława Strzemińskiego, "Łódzkie Towarzystwo Naukowe. Sprawozdania z czynności i posiedzeń naukowych" 1982 nr 5, s. 4). Również w Na kołach wyodrębnienie tekstu w środku miałoby służyć wskazaniu jego odmiennego charakteru. 
w liście do Przybosia nazwę grupy „a.r." jako „awangardę rzeczywistą" ${ }^{37}$ : jej "rzeczywistość" nie polega jednak jedynie na przyznaniu jej słuszności czy pierwszeństwa. Zasadza się na wyobrażeniu, że sztuka eksperymentalna jest realnością: nie naśladuje jej i nie odzwierciedla, ale się w nią przeobraża. Słowo przestaje więc funkcjonować jako wyraz wdrukowany w papier; zaczyna się „toczyć na kołach", wprawione w ruch, wydostaje się niejako z książki, przekracza ramy konwencjonalnego wersu, nie kręci się już po okręgu wyznaczonym przez tradycyjne układy wierszowe, nie poddaje się dyktatowi jednej czcionki, zapisu od lewej do prawej. Nowa typografia uniezależnia je i pozwala wyprzedzić świat i towarzyszące mu przesądy czy iluzje. Wiersz dromoskopowy staje się tym samym wierszem wiecznie prącym naprzód, pozostawiającym za sobą skostniałe idee, ścigającym się z zewnętrznością i pragnącym wyrwać się z zaklętego koła iluzorycznych przedstawień (także tych tworzonych przez awangardowych „poetów-budownicznych”). Jawi się jako arcyawangardowy, gdyż próbuje prześcignąć przede wszystkim sam siebie.

Ta idea nieustannego ubiegania i dystansowania przeciwnika w Na kołach nie jest już tylko opisywana czy wzmiankowana. Przyczynia się ona do stworzenia nowego typu metafory, która u Przybosia będzie się pojawiać już do końca jego twórczej drogi:

stacje ruszyły z miejsca

wyprzedzając spóźnionych podróżnych, trotuar staje z jezdnią do biegu.

Janusz Sławiński o podobnych zabiegach pisał jako o „metonimicznej reinterpretacji związków między rzeczami" ${ }^{38}$, przywołując zresztą sformułowaną przez Kazimierza Wykę zasadę fałszywego sprawcy ${ }^{39} \mathrm{i}$ określając analogiczne strategie zbiorczo mianem poetyckiej fantastyki $i^{40}$ :

Akt poznawczy utrwalony w słownej definicji inicjuje proces stawania się zjawisk, uruchamia przedmioty przedstawione w obrazie. O ich stawaniu

37 Listy Władysława Strzemińskiego do Juliana Przybosia z lat 1929-1933, oprac. A. Turowski, „Rocznik Historii Sztuki" 1973 t. IX, list z dn. 5 VII 1930.

J. Sławiński Koncepcja języka poetyckiego awangardy krakowskiej, Universitas, Kraków 1998, S. 197.

Zob. K. Wyka Wola wymiernego kształtu, w: tegoż Rzecz wyobraźni, Kraków 1997, s. 248. 
się decyduje odniesienie do stanowiska, z jakiego są postrzegane. Dynamika zjawisk jest tu wynikiem aktywności obserwacyjnej ,ja”.41

To podmiot jest w pełni odpowiedzialny za stworzenie „ruchomego obrazu", którego powstanie warunkuje jego sytuacja percepcyjna określana przez podróż, przemieszczanie się. Przyboś opisuje zjawiska jako wzajemnie się wyprzedzające, gdyż nie dostrzega już w poklatkowanym obrazie związków przyczynowo-skutkowych: pęd je odwraca i zaburza. Mijany obiekt nie zostaje w tyle, podłożony pod koła samochodu niczym w Na uskrzydlonych kołach: tutaj wyrusza w drogę, podejmuje wyzwanie rzucone przez inne uruchomione przedmioty i staje z nimi do wielkiego wyścigu. Jego cel i meta stają się jedyną realnością. U Przybosia odnajdziemy podstawową cechę Viriliańskiej dromoskopii - kurczenie się przestrzeni między rzeczami, redukcję podróży do punktu dojścia, który jest nieustannie tuż przed nami, który pragniemy usilnie przegonić.

In simulating the fleeting nature of things that abide, the means of transmission makes evident the improbable reality of an end of space, the dromoscopic simulation makes the falsehood of a contraction of the world plausible.

The animation of the dashboard misleads voyagers regarding the catalysmic movement of the end, regarding the destination of the end; like a magical mirror, the windshield allows us to view the future. ${ }^{42}$

[W pozorowaniu przemijającej natury rzeczy, które trwają, środki transmisyjne czynią niepodważalną nieprawdopodobną realność końca przestrzeni; symulacja dromoskopowa czyni fałszywe kurczenie się przestrzeni czymś wiarygodnym.

Animacja deski rozdzielczej oszukuje podróżujących co do przyspieszającego ruchu ku końcowi, co do punktu dojścia jako takiego. Niczym magiczne lustro, przednia szyba pozwala nam oglądać przyszłość.]

W percepcji dromoskopowej punkt dojścia staje się jedyną oczywistością: zanika już zmierzanie ku niemu, zanika radość związana z kontemplacją tego, co mijane. Jedyną ambicją staje się jak najszybsze dotarcie do celu podróży: tak, aby żaden z oglądanych elementów nie mógł nas już wyprzedzić i ubiec

\footnotetext{
41 Tamże, s. 197.

P. Virilio Negative..., s. 105.
} 
na mecie. Strategia ujawniona w Na kołach Przybosia pokazuje właśnie ów paradoks coraz większej prędkości: rzeczywistość obserwowana nieustannie wyprzedza tam samą siebie, uniemożliwia procesualność, rozwijanie się wypadków w ich naturalnym czasie. Ów przestaje bowiem spełniać swoją podstawową funkcję porządkującą, szeregującą zdarzenia. Przez „magiczne lustro" przedniej szyby widzimy jedynie rozciągającą się przed nami przyszłość, która anuluje nie tylko to, co minęło, ale także to, co aktualnie trwa. Sprawia, że pozostawiamy w tyle nawet te fragmenty przestrzeni, które są nam potrzebne: droga zrywa się w tekście Przybosia, nie ma już czym jechać dalej, architekci nie nadążają (zupełnie przeciwnie niż w Śrubach czy Oburacz) za potrzebami dromoskopowego podmiotu.

Nagle okazuje się, że znajdujemy się w paradoksalnej sytuacji oczekiwania na nadejście spóźnionej realności: ja musi samo zacząć kreować rzeczywistość dla siebie, gdyż prawdziwa, obserwowana zniknęła i zagubiła się w przeszłości:

Dromoscopy is, therefore, paradoxically the wait for the coming of what abides: the trees that file past on the screen of the windshield [...] all substitudes for reality, these apparent movements are only simulacra. ${ }^{43}$ [Dromoskopia jest więc, paradoksalnie, oczekiwaniem na to, co trwa: drzewa, które przechowują przeszłość na ekranie przedniej szyby [...] wszelkie substytuty realności, wszystkie te pozorne ruchy to tylko symulakra.]

Architekt z wiersza Przybosia zostaje zmuszony do wyprodukowania na potrzeby pędzącego podmiotu kolejnej, symulakrycznej jezdni. Wykorzystuje powtarzalność przestrzeni i reprodukuje ją - uobecnia przeszłość w owej wyprzedzającej wszystko przyszłości. Teraźniejszość zostaje zupełnie wyrugowana z paradygmatu dromoskopowego. Budowniczy „łapie” jedynie (niczym kierowca owe „zarchiwizowane drzewa” z eseju Virilio) przelatujące mu przed oczami trakty:

z placów, porosłych kołami, lecą

gościńce, które inżynier przedłuża

o rozpęd nóg zadyszanych przechodniów. 
"Lecące gościńce” wydają się jakimiś resztkami, skrawkami niegdyś stabilnej przestrzeni, która teraz uległa całkowitemu rozproszeniu. Kiedyś panował nad nią głównodowodzący inżynier, planista odpowiedzialny za zbilansowany rozwój metropolii. Teraz, wyrwała się ona niejako spod kontroli; sama - niczym poddana dromomaniakalnemu dyktatowi motorycznemu - zerwała się z uwięzi. Nadmierna eksploatacja przestrzeni (stawanie z nią nieustannie w szranki, modyfikowanie, kreowanie spektaklu sfabrykowanego świata) doprowadziło do rewolucji - ona właśnie ukształtowała tekst dromoskopowy, pragnący na nowo ustanowić relację między ja a światem:

territory is exploited by the acceleration of displacement, as if the consumption of space and time follows upon and repeats the consumption of raw materials. ${ }^{44}$

[terytorium zostaje wyzyskane przez przyspieszone przemieszczanie się, zupełnie jakby konsumowanie czasu i przestrzeni prześcigało i powtarzało konsumowanie surowego materiału.]

Podmiot wiersza Przybosia wciela wszelkie zasady dromomaniakalnego podróżowania: jego ruch jest kompulsywny, konieczny, niemożliwy do opanowania. Prowadzi on do zanikania realnie istniejących miejsc i do zaburzenia relacji czasowych. Świat staje się tam - niczym w początkowych realizacjach z pierwszych tomów - „materiałem” dla stworzenia nowej rzeczywistości. Spektakl faktycznie zdaje się początkowo napędzany siłą reżysera-kierowcy, który wydaje polecenia z wnętrza swego "command car"45 [pojazdu dowodzącego]. Jak pisze Virilio:

If speed is light, all the light of the world, then what is visible derives both from what moves and the appearances of momentary transparancies and illusions. The dimensions of space, are themselves only fleeting apparitions, in the same way that things are visible in the instant of the trajectory of the gaze, this gaze that both is the eye [l'oeil] and that defines place [le lieu]. ${ }^{46}$

\footnotetext{
44 Tamże, s. 109.

45 Tamże, s. 107.

46 Tamże, s. 113.
} 
[Jeśli prędkość jest światłem, wszelkim światłem świata, wówczas widzialność wynika zarówno z tego, co się rusza, jak i ze zjawiania się momentalnych transparentów i iluzji. Wymiary przestrzeni są jedynie ulotnymi widziadłami, w taki sam sposób jak rzeczy widziane w natychmiastowości biegu spojrzenia, spojrzenia, które jednocześnie jest okiem i definiuje przestrzeń.]

Francuski myśliciel zwraca uwagę na dwie przenikające się zasady: z jednej strony (i to udało nam się już zaobserwować w wierszu Przybosia) to ruchomy podmiot decyduje o charakterze swojego spojrzenia. To on jest odpowiedzialny za zerwanie perspektywy, negację jej punktu zbieżnego i prezentowanie przestrzeni jako zbioru „spojrzeń ruchomych". Widać to zarówno we wczesnych tekstach, jak i w pojedynczych lirykach ze Z ponad. Słynny początek Spojrzeć mówi o tym dosadnie:

Spojrzeć - a ze spłoszonych miejsc samochody rozwożą miasto. ${ }^{47}$

Metropolia nie jest czymś względem człowieka patrzącego zewnętrznym: to kierowcy samochodów decydują o jej kształcie, rozwożąc ją (i jej obraz) ulicami. To od nich zależy, czym ona się stanie i w co przeobrazi. Jednocześnie - idąc tropem Viriliańskiego eseju - od tekstu dromoskopowego wymagamy czegoś więcej. Nie tylko reżyserowania miejsc (ten typ wyobraźni możemy obserwować w ramach poetyki konstruktywistycznej), ale także ich doświadczania w zjawianiu się. Być może każdy obraz wyświetlony na szybie nosi na sobie piętno iluzoryczności; zderzenie się z nim jednak, zaufanie żywemu o k u, pozwala wydostać się z „obiegu”, jaki stworzyła dla nas kategoria „poety-inżyniera”, architekta zbiorowej wyobraźni. Zakończenie wiersza wewnętrznego umieszczonego w Na kołach zbliża nas do owego wyzwolenia:

ulicę - od rogu do rogu zalewają domy,

domów - po dachy przybrało, nadmiar dzieło pod dach wyprowadza codnia.

Zamknięcie pokazuje, że spektaklu nie sposób już dalej kontrolować. Przyboś prowadzi swojego czytelnika na skraj wybuchu, katastrofy. Tworzy obraz

47 J. Przyboś Z ponad, s. 14. 
napięty do granic możliwości, w którym pierwsza faza anihiliacji władczego podmiotu już się dokonała (ulica została zalana przez domy, pędzący nią tłum zmiażdżony przez napierającą przestrzeń), druga zaś (wybuchy pojedynczych kamienic niemieszczących się już pod własnymi dachami) - za chwilę się rozpocznie.

Tekst dromoskopowy dąży więc do kolizji: między „ja” a światem, między projektującym spojrzeniem a niedającą się zaprojektować i okiełznać rzeczywistością. U Przybosia ów moment przejścia - przelatywania podmiotu przez przednią szybę rozpędzonego auta - widziany właśnie w $Z$ ponad: tam, gdzie dogorywa konstruktywistyczny paradygmat, ustępując miejsca wyobraźni wiecznie poruszonej, nie tylko rejestrującej, ale też uczestniczącej w przestrzennych konfiguracjach, jednocześnie atakującej i atakowanej. Virilio przedstawia nam bardzo sugestywny obraz owego (wydawać by się mogło, mało spektakularnego) „wypadku widzenia”:

dromoscopic accidents are less spectacular, it seems, in their immediate consequences, than collisions, no wreck remains and nobody is visibly concerned about the security of vision. However, faced with this vertigo that affects the passanger while he dives into the depths of the landscape, we should pause to reflect; this intoxication of grandeur that drives us to pass certain levels of acceleration is formidable. ${ }^{48}$

[wypadki dromoskopowe są mniej spektakularne, jak się wydaje, w swoich natychmiastowych konsekwencjach, niż faktyczne kolizje, nie pozostawiają żadnego wraku i nikt tak naprawdę nie przejmuje się bezpieczeństwem obrazu. Jednak, odczuwając ów zawrót głowy, który przydarza się pasażerowi, kiedy nurkuje w głębi krajobrazu, powinniśmy się zatrzymać i zastanowić; owo zatrucie wspaniatościa, które zmusza nas do przekraczania kolejnych poziomów przyspieszenia, jest wyjątkowo potężne.]

Kolizja, do której tu dochodzi, nie rozegra się w rzeczywistej przestrzeni, ale w zaprojektowanym dla niej wierszu; jednak mimo to poczucie przyspieszenia prowadzącego podmiot do zagłady, do samonegacji, jest czymś zupełnie realnym. Tekst dromoskopowy staje się więc miejscem uobecnienia się pragnienia katastrofy: zapomnienia się w pejzażu, jego jednoczesnego zawłaszczenia i oddania mu się we władanie. Od utworu, który jedynie opisywał

48 P. Virilio Negative..., s. 108. 
kolejne fazy ruchu, zostajemy przeniesieni do wiersza będącego ruchem ku nicości, przyspieszającego na naszych oczach, złapanego w momencie przed wybuchem: ostatecznym pojednaniem z Viriliańskim grandeur - majestatem nie-i-prawdziwym, zawieszonym między naszym projektującym okiem i samym miejscem.

\section{Abstract}

\section{Michalina Kmiecik}

JAGIELLONIAN UNIVERSITY (CRACOW)

The Avant-Garde and the Dromoscopic Text

This article aims to show how the avant-garde anthropological paradigm (based on notions of movement, progress, speed) relates to the philosopher Paul Virilio's concept of dromoscopy. Virilio examines problems such as de-identification, loss of a stable subjectivity, the creation of an image of the human-projector that produces simulacra on the dashboard display. Kmiecik takes up these problems to develop the idea of the dromoscopic text, which, rather than thematizing movement, attempts to make it present in poetic language. To describe the transformation of avant-garde poetry, which strives from a fascination with the dromomaniacal subject towards dromoscopic discernment, Kmiecik uses two poems by Julian Przyboś as examples: Na uskrzydlonych kołach [On Winged Wheels] and Na kołach [On Wheels].

\section{Keywords}

avant-garde, dromoskopia, Julian Przyboś, Paul Virilio 